Article

\title{
Sharing Benefits in Transboundary Rivers: An Experimental Case Study of Central Asian Water-Energy-Agriculture Nexus
}

\author{
Shokhrukh-Mirzo Jalilov *, Olli Varis and Marko Keskinen \\ Water \& Development Research Group, Aalto University, Aalto 00076, Finland; \\ E-Mails: olli.varis@aalto.fi (O.V.); marko.keskinen@aalto.fi (M.K.) \\ * Author to whom correspondence should be addressed; E-Mail: shokhrukh.jalilov@aalto.fi; \\ Tel.: +358-46-6171001.
}

Academic Editor: Miklas Scholz

Received: 17 June 2015 / Accepted: 27 August 2015 / Published: 2 September 2015

\begin{abstract}
Cooperation in transboundary river basins is challenged by the riparian countries' differing needs for water use. This is the case especially in Amu Darya Basin in Central Asia, where upstream Tajikistan is building the Rogun Hydropower Plant (RHP) to increase its energy security, while the downstream countries oppose the plant due to the feared negative impacts to their irrigated agriculture. Several experimental scenarios illustrate how the concept of benefit sharing could be used as a framework to investigate these water-energy-agriculture linkages in a transboundary context. Using a hydro-economic model, we investigate the economic benefits of various scenarios emphasizing agricultural and/or energy production, thus benefiting the riparian countries uniquely. Subsequently, we discuss how benefit-sharing arrangements with different forms of compensations could be used as a mechanism to facilitate transboundary cooperation. Our results indicate that several scenarios have a potential to increase the total energy-agriculture benefits in the basin. Yet, agreeing on the actual benefit-sharing mechanism between the countries poses special challenges as each may require countries to give up some of their anticipated maximum potential benefits. The presented scenarios provide a potential starting point for debates over benefit-sharing arrangements across countries needing to address the water-energy-agriculture nexus.
\end{abstract}

Keywords: benefit-sharing; water-energy-agriculture nexus; water allocation; hydro-economic modeling; Rogun; Amu Darya 


\section{Introduction}

The principle of benefit-sharing has been proposed as a strategy to facilitate the cooperation on transboundary river basins to address a wide range of water uses such as agriculture and energy production [1-4]. The main idea behind benefit-sharing is not to share physical quantities of water, but rather to share the benefits arising from water development and use [2]. Benefit-sharing thus builds on the assumption that the beneficiaries - in transboundary river basins, the riparian countries - are more interested in the economic value and benefits that water and its development creates, rather than dividing up a fixed quantity of water itself. In ideal benefit-sharing situations, the riparian countries view the benefits of water development and use as a positive-sum game associated with benefits optimization, rather than the zero-sum game associated with simple water sharing [5]. Such benefits are often economic, but can also include, for example, social, political or environmental benefits, and various mixes between these [6].

Sadoff and Grey [1] identified four types of cooperative benefits: benefits to the river, benefits from the river, reduced costs because of the river and benefits beyond the river. This study focuses on the second type of benefits (from the river), where cooperative management of shared rivers can yield major benefits in terms of increased food and energy production. Benefit-sharing may also include some form of redistribution of benefits or compensation for lost benefits. While, the actual form of compensation is highly situation specific, it can involve for example monetary transfers, granting of rights to use water, financing of investments, or the provision of non-related goods and services [2].

This article presents an experimental case study looking at the possibility for benefit sharing in the Amu Darya River Basin (ADRB). The focus of the study is on the economic benefits that the riparian countries could receive from the planned Rogun Dam and its operation on the Vakhsh River, tributary to Amu Darya. The Rogun Hydropower Plant (RHP) is a controversial project, and there have been active debates (mostly on websites such as www.eurasianet.org, www.fergananews.com and centrasia.ru) about its benefits, revolving around Tajikistan's aim to enhance its energy security and Uzbekistan's concerns about the negative impacts on its agriculture.

Despite the on-going debates, there has been little scientific research investigating the actual level or distribution of economic benefits that various operation schemes of the Rogun Reservoir enables for riparian countries. In addition, existing studies e.g., [7-9] look mainly at basin-wide benefits, thus assuming that the riparian countries would be willing to negotiate and agree on the most optimal operation scheme. Yet, this is not obvious in the study context, as there is currently no sign of willingness among the riparian countries to reach mutual agreement on the operation of the Rogun Reservoir [10,11].

As a result, this study takes the view of quantifying the economic benefits for operation schemes emphasising each riparian country's priorities and then comparing those with operation scheme optimising basin-wide benefits. After this, we use the concept of benefit-sharing to investigate different possibilities that could serve as a basis for the operation of the Rogun Dam and Hydropower Plant in a way that brings about a Pareto improvement (economic welfare gain) satisfying all riparian countries. We hope that such approach will provide a meaningful contribution to current policy debates around the Rogun Dam, initiating discussion, dialogue, and debate about innovative measures to investigate at the benefits derived across the water-energy-agriculture nexus in the Amu Darya River Basin. 


\section{Material and Methods}

\subsection{Case Study Basin}

The Amu Darya River is the largest river in Central Asia in terms of its length of $2540 \mathrm{~km}$ [12], as well as its average annual supply of some 65 cubic kms [13]. The mainstream is supplied by the confluence of two main tributaries, the Vakhsh and Pyandj Rivers, and the river terminates in the Aral Sea (Figure 1). The river basin is shared by five riparian countries of Afghanistan, Kyrgyzstan, Turkmenistan, Tajikistan, and Uzbekistan. The Basin's drainage area includes about 309,000 km² [14] and is home to approximately 55 million people [15]. On its route from the headwaters to the Aral Sea, the River borders Afghanistan and Tajikistan as well as Afghanistan and Uzbekistan. For this reason, there have been considerable policy debates for years on approaches to manage water for the competing users and uses in the Basin.

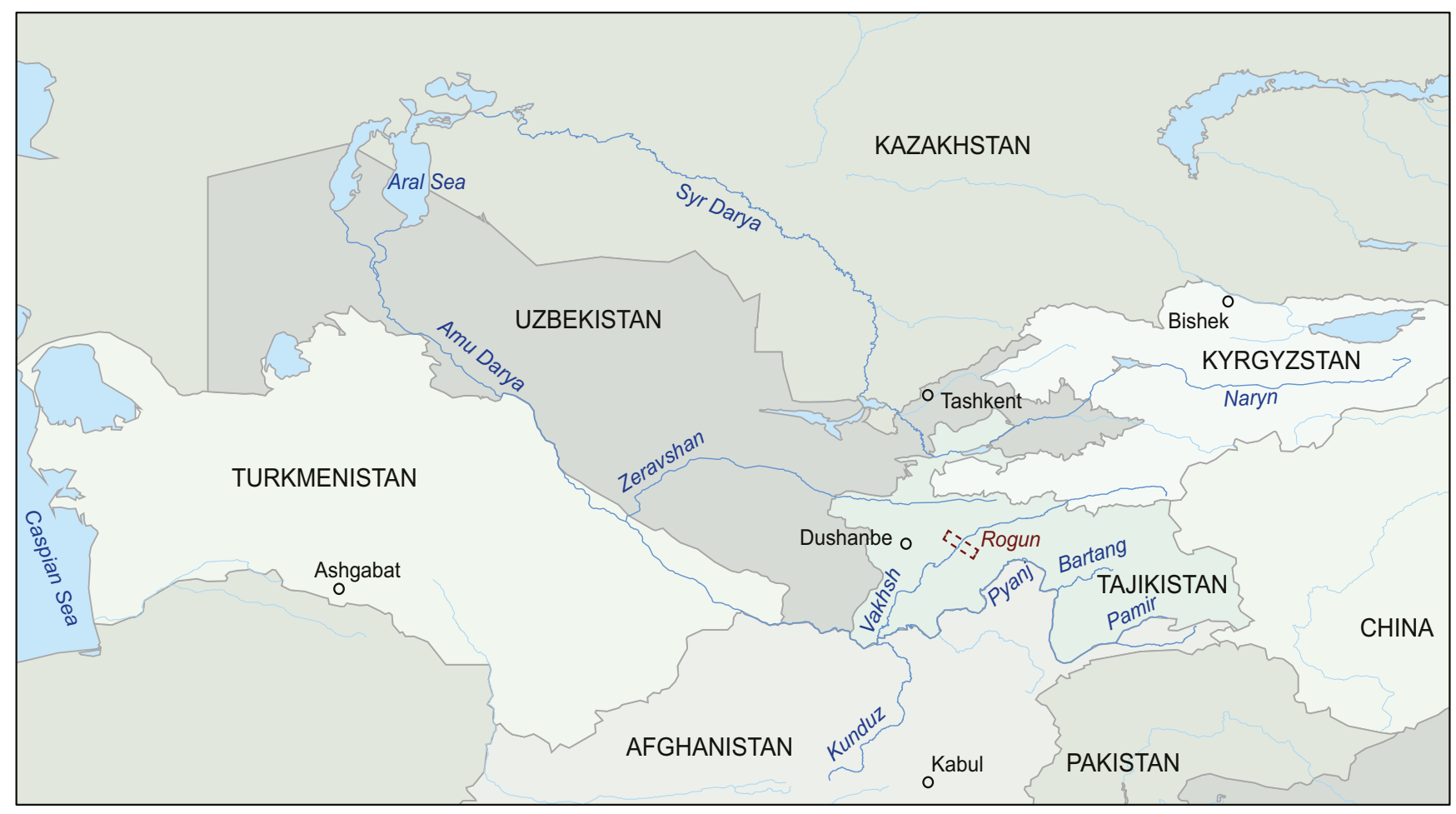

Figure 1. Map of Central Asia with the location of the Rogun Dam.

The basin presents a unique case of transboundary water management, as before 1991 the area was part of the former Soviet Union and the majority of the river basin (except for Afghanistan) was managed by a single, central government under a common political system. At that time, the water use in the basin emphasized large-scale agricultural production (primarily cotton and wheat) and reservoirs were built in the upstream Tajikistan to provide water storage for the downstream irrigation demands see also [14,16-18]. As such, the situation before 1991 thus resembled a kind of benefit-sharing scheme, where the Republics of the Soviet Union shared and optimized benefits from the river based on barter relations.

After the dissolution of the Soviet Union in 1991, the Amu Darya became a transboundary river flowing through five independent states. Kyrgyzstan supplies $2 \%$ of total flow in the basin [19] and according to the "Agreement on Cooperation in Joint Management, Use and Protection of Interstate 
Sources of Water Resources" signed in February 1992 entitled to use only $0.6 \%$ of annual flow. Due to such small shares this country has not been considered in the study. The water management practices changed fundamentally, as the newly-independent countries focused on maximizing their individual benefits that the river and its water resources could provide, often at the expense of their neighbors.

To resolve the problem with its growing energy deficit, in 2008 Tajikistan announced its intention to resume the construction of $335 \mathrm{~m}$ high Rogun Dam on the Vakhsh River, a tributary to the Amu Darya River [20]. The construction of the Dam was already started during the Soviet era time in 1976, but halted in 1991 with the breakup of the Soviet Union. The purpose of the Rogun Dam is to supply the upstream Tajikistan with hydropower, but downstream countries oppose the dam due to possible negative impacts that the changed flow regime is expected to cause to downstream agriculture. Hence, while Tajikistan is in a hydrologic position to decide unilaterally on the operation of the Rogun Dam, it could also make friends by operating the dam to facilitate transboundary cooperation by considering the benefits of other riparian countries as well.

\subsection{The Modeling Framework}

An integrated river basin model was developed to estimate the benefits resulting from the various possible operation schemes (scenarios) of the Rogun Dam. Such operation schemes investigated three individual (country-specific) and two cooperative schemes, and focused on two of the most important water uses, i.e., hydropower generation and agricultural production in the Amu Darya River Basin. In addition, environmental water need is included into the model through a constraint that ensures a $10 \%$ minimum flow at the confluence of Vakhsh and Pyanj must inflow to the Aral Sea at any given time period.

The model is an extension of the previous Amu Darya model [9], in which the main tributary flows are allocated to aggregate downstream water demands for beneficial use. The previous study provided empirical evidence for ways to achieve basin-wide Pareto efficiency by improving outcomes over shared transboundary waters, outcomes in which all riparian countries could be made better off by sharing the benefits of water development and allocation. In this study, the model framework is updated to include new operation schemes looking at country-specific benefits: under such schemes, the model maximizes the economic benefits for each country with no consideration of the total basin-wide benefits.

The model considers the economic importance of irrigated agriculture in the four basin countries, (Afghanistan, Tajikistan, Turkmenistan, Uzbekistan) in addition to the potential for hydropower production in upstream Tajikistan. The model allocates water for energy and agricultural production over a 10-year period with a monthly time step. The model considers two cropping seasons, with the first (early planting) crop season starting in March and lasting until August and the second, i.e., so-called mid-term crop starting in May (late planting) and lasting until early autumn. Altogether three key crops are included: cotton as a strategic cash crop for Uzbekistan and Turkmenistan and wheat and potato as crops ensuring food security for all the riparian countries.

The integrated hydro-economic river basin model consists of hydrologic, agronomic, and economic elements, with an emphasis on the economic element. It is nonlinear, and programmed using the GAMS language [21]. The basin scale integrated model maximizes discounted net present value (NPV) across all water uses (in this case agriculture and energy), and all time periods subject to hydrologic and institutional constraints. NPV is the sum of present values of future benefits and costs. Discounted net 
present value is equal to the sum of agricultural and energy benefits. The model allocates water among the basin's water uses, locations, and time periods to maximize net present value, subject to the described constraints.

The river basin framework is developed as a node link network, which is a representation of the spatial objects in the river basin. Nodes represent river flows, reservoir, and demand objects, and links represent the linkages between these objects (Figure 2). Runoff from headwaters in the river basin constitutes inflows to these nodes. Balance between flows is calculated for each node at each time period, and flow move is calculated on the spatial connection in the river basin geometry (Appendix A).

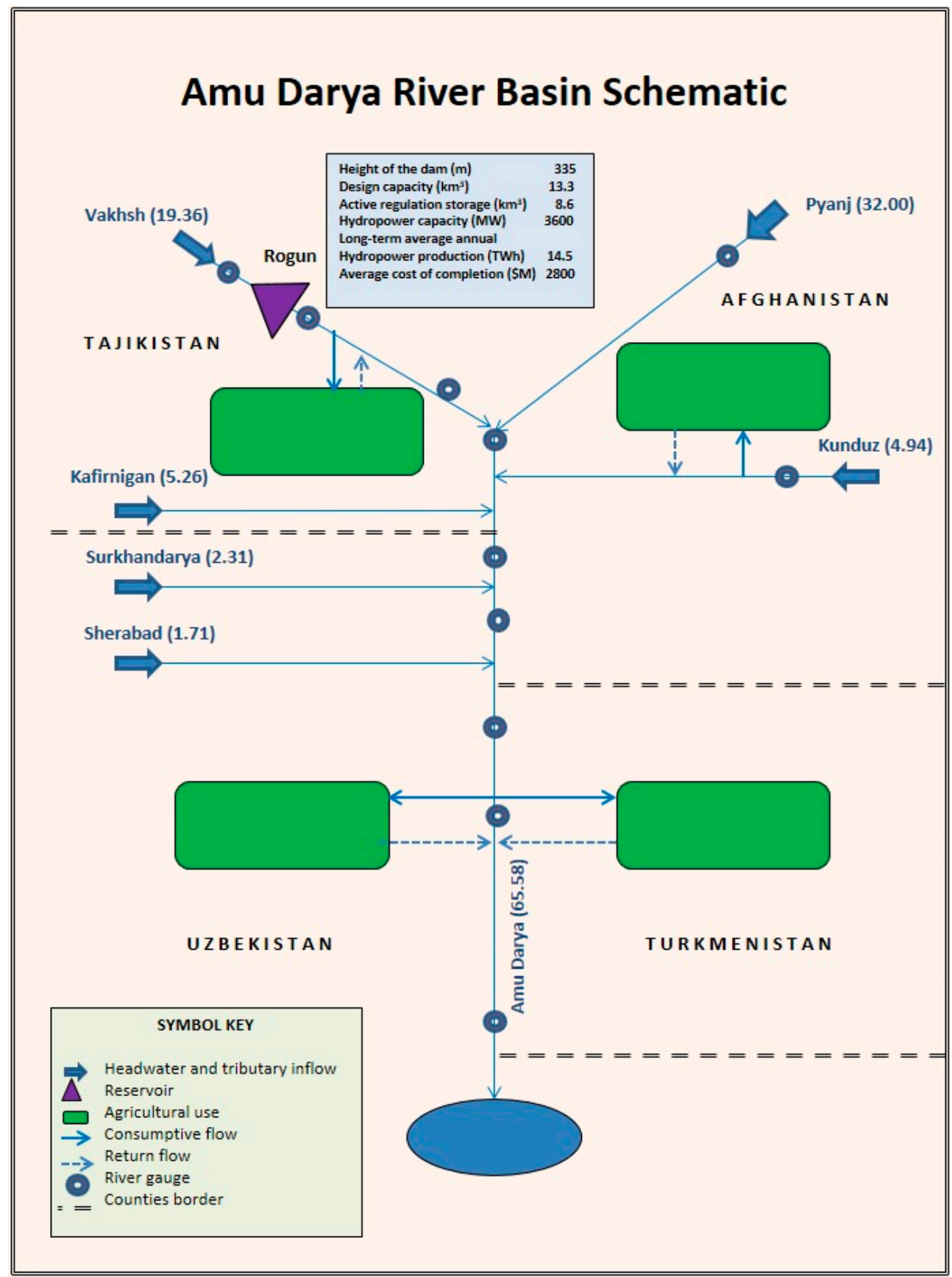

Figure 2. The schematic of the ADRB, including the design characteristic of the Rogun Hydropower Plant [9] and average annual water flow (billion cubic meters/year) of the Amu Darya tributaries used in the model [22]. 


\subsection{Data Used in the Model}

Figure 2 shows schematic of the Amu Darya and information on average annual water supply by source as well as the design data for Rogun Dam and Reservoir. The average annual water runoff in the Amu Darya River equals $65.58 \mathrm{~km}^{3}$. The two major tributaries of the Amu Darya, the Pyanj and Vakhsh rivers, constitute $49 \%$ and $30 \%$ of the main river's total flow, respectively.

The economic benefits of hydropower and irrigated agriculture are derived from the use of water for energy and crop production. Crop water use data were used for existing cropping patterns by country and crop, and combined with agricultural production details including crop prices, production costs, and crop yields (Table 1). Net agricultural income per hectare and total land in production by country, crop, and season were identified. Agricultural income per land unit for each crop was defined as crop price multiplied by yield minus costs of production.

Table 1. Agricultural data by country and crop. The total land area in production indicates the sum for all three crops. Source: [23].

\begin{tabular}{|c|c|c|c|c|c|}
\hline Country & Crop & $\begin{array}{c}\text { Yield } \\
\text { (tons/ha) }\end{array}$ & $\begin{array}{c}\text { Cost } \\
\text { (\$US/ha) }\end{array}$ & $\begin{array}{c}\text { Water } \\
\text { Requirements } \\
\left(\mathbf{m}^{3} / \text { ha per year }\right)\end{array}$ & $\begin{array}{c}\text { Total Land Area in Production } \\
\text { within Amu Darya Basin (million ha) }\end{array}$ \\
\hline \multirow{3}{*}{ Tajikistan } & cotton & 1.8 & 444 & 12 & \multirow{3}{*}{0.5} \\
\hline & wheat & 1.5 & 168 & 8 & \\
\hline & vegetable & 12 & 500 & 12 & \\
\hline \multirow{3}{*}{ Afghanistan } & cotton & 1.8 & 444 & 12 & - \\
\hline & wheat & 1.6 & 165 & 8 & 0.4 \\
\hline & potato & 12 & 503 & 12 & - \\
\hline \multirow{3}{*}{ Uzbekistan } & cotton & 2.3 & 390 & 14 & - \\
\hline & wheat & 1.5 & 283 & 6 & 2.3 \\
\hline & vegetable & 11 & 702 & 11 & - \\
\hline \multirow{3}{*}{ Turkmenistan } & cotton & 2.2 & 392 & 14 & - \\
\hline & wheat & 1.5 & 283 & 6 & 1.1 \\
\hline & vegetable & 11 & 702 & 11 & - \\
\hline
\end{tabular}

Discounted net farm income was summed over crops, time periods, and countries, subject to water supply and sustainability constraints described subsequently. Consistent with neoclassical price theory, reduced water quantities supplied to agricultural users decrease crop production and raise crop prices. Prices are based on previously published work that estimated price elasticities of demand and a linear demand price response at historically-observed prices and production levels in the entire region. This means that the model considers all countries as a unified and linked market and allocates water to the country where cost of production is lower and profit is higher.

Since the energy price is currently regulated by the Tajik government, the benefits from the energy production (hydropower) were derived by multiplying energy production by a constant energy price. Energy production is unknown in advance and part of the optimized model results, but as a matter of principle, it depends on the head of falling water, water discharge, gravitational acceleration, and a coefficient representing the technical efficiency of turbines by which falling water is converted into 
power. The model of energy production closely reproduced the maximum energy capacity of the Rogun Reservoir that is used in most of the recently-published planning documents [24].

The analysis requires the Rogun Reservoir to be filled to its maximum capacity by the last period (end of the 10th year). By establishing this constraint on the terminal period's reservoir level, sustainable water supplies and use and operation modes are protected. In addition, the model was calibrated by fitting model predictions suitably close to observed historical values of crop production and crop land pattern in each basin country in the baseline scenario.

\subsection{Scenarios Examined}

One baseline and five alternative model scenarios were considered as options to examine the economic benefits from the RHP for the riparian countries: (1) Baseline without the Rogun Dam; (2) Upstream Energy Priority (Tajikistan); (3) Uzbekistan Priority; (4) Turkmenistan Priority; (5) Downstream Agriculture Priority (Uzbekistan and Turkmenistan); and (6) No Priority ("optimal") (Figure 3). Afghanistan was not included in these operation schemes as it is not a major water user in the basin, yet its water use was included in the actual model results (Table 2).

Table 2. Total discounted economic benefits over 10 years for five scenarios, by country and the basin (million US\$, NPV 5\%).

\begin{tabular}{cccccc}
\hline \multirow{3}{*}{ Country } & Scenario & Agricultural & Energy & \multicolumn{2}{c}{ Total benefits } \\
\cline { 5 - 6 } & Benefits & Benefits & \$US & $\begin{array}{c}\text { \% Change from } \\
\text { the Baseline }\end{array}$ \\
\hline \multirow{5}{*}{ Tajikistan } & Baseline without Rogun Dam & 2268 & - & 2268 & 100 \\
& Upstream Energy Priority & 2210 & 3679 & 5889 & 160 \\
& Uzbekistan Priority & 1676 & 3981 & 5657 & 149 \\
& Turkmenistan Priority & 1703 & 3970 & 5673 & 150 \\
& Downstream Priority & 1310 & 3488 & 4798 & 112 \\
& Optimal-No Priority & 3084 & 3485 & 6568 & 190 \\
\hline \multirow{5}{*}{ Afghanistan } & Baseline without Rogun Dam & 192 & - & 192 & 100 \\
& Upstream Energy Priority & 339 & - & 339 & 76 \\
& Uzbekistan Priority & 188 & - & 188 & -2 \\
& Turkmenistan Priority & 192 & - & 192 & 0 \\
& Downstream Priority & 184 & - & 184 & -4 \\
& Optimal-No Priority & 462 & - & 462 & 140 \\
\hline \multirow{5}{*}{ Uzbekistan } & Baseline without Rogun Dam & 26,588 & - & 26,588 & 100 \\
& Upstream Energy Priority & 29,579 & - & 29,579 & 11 \\
& Uzbekistan Priority & 37,895 & - & 37,895 & 43 \\
& Turkmenistan Priority & 9097 & - & 9097 & -66 \\
& Downstream Priority & 35,668 & - & 35,668 & 34 \\
& Optimal-No Priority & 30,155 & - & 30,155 & 13 \\
\hline
\end{tabular}


Table 2. Cont.

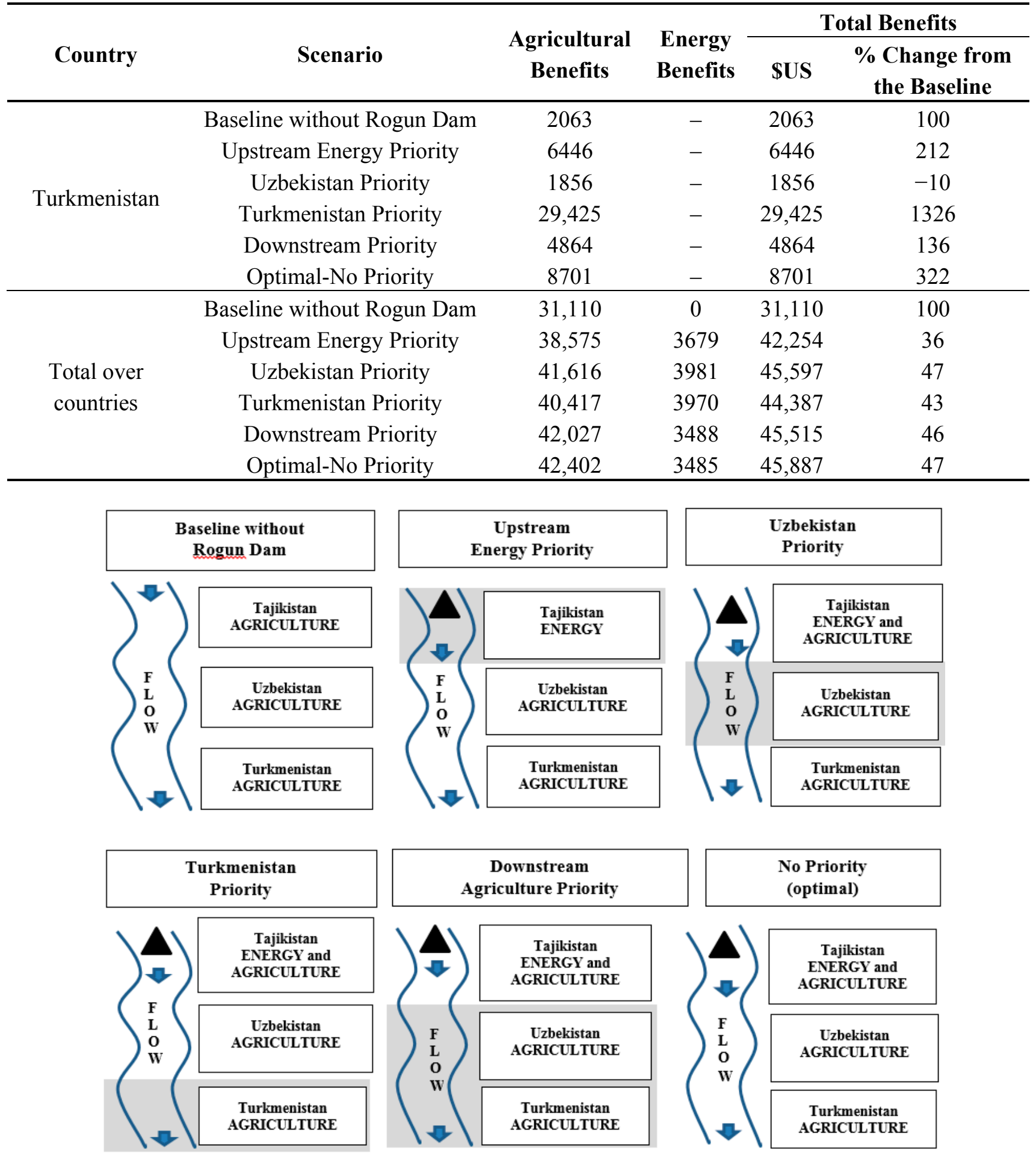

Figure 3. The scenarios modeled in the framework. Shaded area indicates the priority under each scenario, while black triangle indicates the Rogun Dam. 
The baseline was included in the model by constraining the irrigation in the basin to closely reproduce historical agricultural land under production in each riparian country without the Rogun Dam. This created the baseline within which the five scenarios (with the Rogun Dam) can be compared. Below, the constraints included in the scenarios are presented.

\subsubsection{Upstream Energy Priority (Tajikistan)}

The first scenario ensures Tajikistan's energy benefits by first optimizing its stated electricity demand and then taking into account the agricultural water use in Tajikistan, as well as other riparian countries. This scheme was modeled so that the Rogun Hydropower Plant must produce at least $70 \%$ of total energy requirements of Tajikistan for each month of a year. The Tajik Aluminum Enterprise (TALCO), which is the only major industrial plant in Tajikistan, consumes about $40 \%$ of the country's electricity [25]. Characteristic to the seasonal pattern of electricity consumption in Tajikistan are two consumption peaks; the bigger in winter due to heating and the lower in summer due to agricultural water pumping [25].

\subsubsection{Uzbekistan Priority}

The second scenario maximizes the agricultural benefits for downstream Uzbekistan with the Rogun Dam. The scheme was modeled so that the agricultural benefits of Uzbekistan with the Rogun Dam must be equal or higher than agricultural benefits without the dam. In addition, other riparian countries' agricultural land area was constrained so that it must be equal or less than their agricultural land without the Rogun Dam.

\subsubsection{Turkmenistan Priority}

The third scenario maximizes the agricultural benefits for downstream Turkmenistan with the Rogun Dam. The scheme was modeled in a similar manner than for Uzbekistan, meaning that the agricultural benefits of Turkmenistan with the Rogun Dam must be equal or higher than agricultural benefits without the dam. In addition, other riparian countries' agricultural land area was constrained so that it must be equal or less than their agricultural land without the Rogun Dam.

\subsubsection{Downstream Agriculture Priority (Uzbekistan and Turkmenistan)}

This scenario first maximizes Uzbekistan's and Turkmenistan's agricultural benefits and thereafter the water uses in Tajikistan and Afghanistan. The Rogun Dam thus operates in so-called irrigation mode, providing water during the vegetation period downstream and storing water in winter. This scheme was modeled so that the agricultural benefits for both Uzbekistan and Turkmenistan with the Rogun Dam must be equal or higher than the agricultural benefits without it. In addition, a constraint was introduced requiring agricultural land area in Tajikistan and Afghanistan with the Rogun Dam to be equal or less than the area without the dam. Such a constraint ensures that there is no shift between crop areas in upstream countries, and allow greater flexibility in choosing which crop to grow for downstream countries. 


\subsubsection{No Priority (optimising basin-wide benefits)}

The last scenario is a so-called optimal scenario where all model constraints except hydrological are removed: the model thus seeks to maximize the basin-wide benefits, instead of the optimal benefits for individual riparian countries. This operation scheme is thus expected to create the largest total economic benefits (agriculture and energy) for the whole basin.

\section{Results}

\subsection{Economic Benefits from Different Modeled Scenarios}

The key results for the economic benefits of the five scenarios are summarized in Table 2, showing the economic benefits summed over 10 years for each country separately as well as total basin-wide benefits. Figure 4 complements the table by summarizing the model results across the years (averaged over the modeled period i.e., 10 years) in terms of the reservoir monthly water discharge and corresponding energy production.

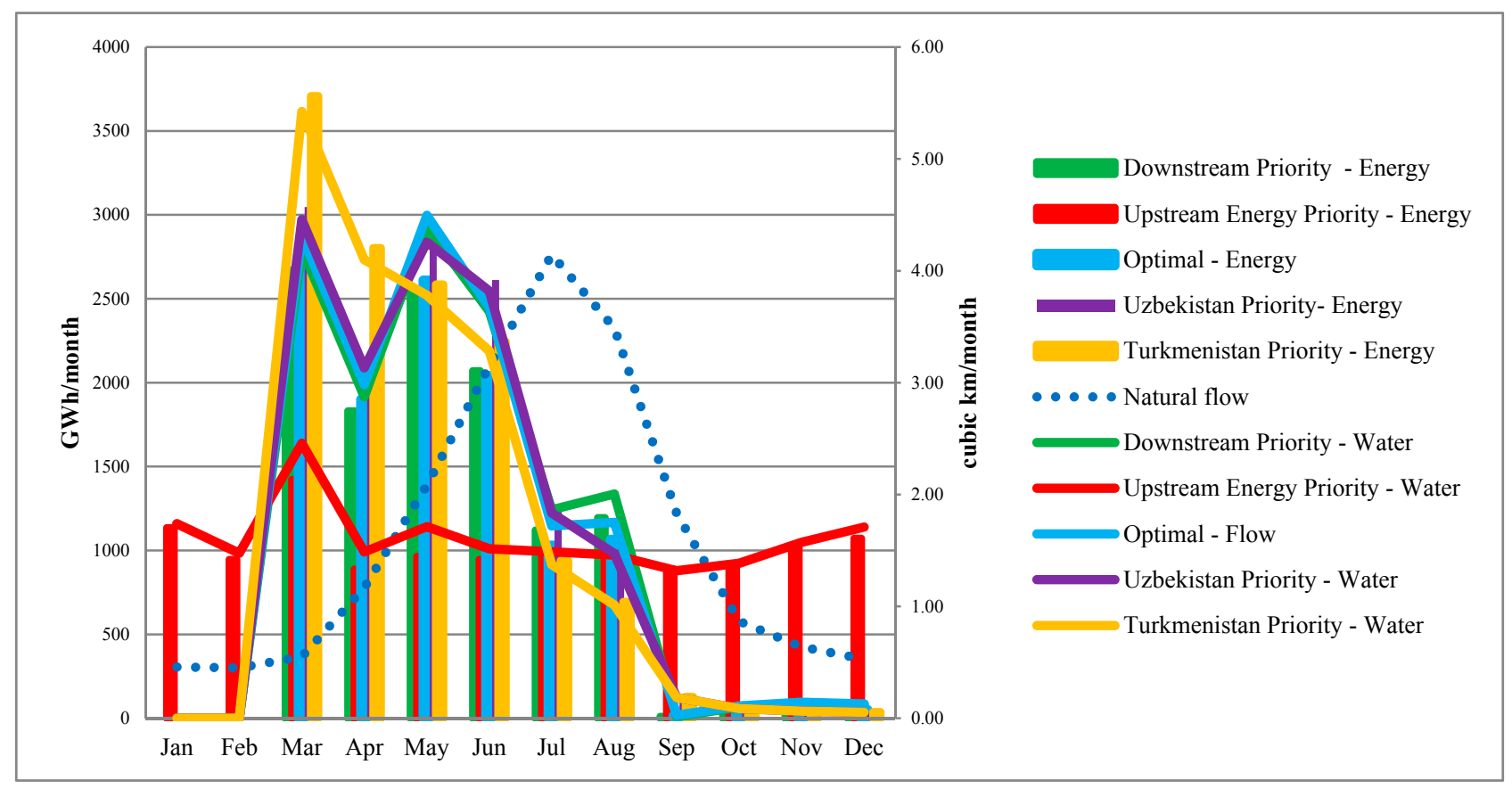

Figure 4. The model results showing monthly water discharge (on right $y$-axis) and corresponding energy production (on left $y$-axis) of the Rogun Hydropower Plant under five scenarios and the baseline (natural flow), averaged over 10 years. As can be seen, all five scenarios would significantly alter the natural flow, with "Upstream Energy Priority" leveling natural flow significantly.

The first key finding emerging from Table 2 is that the total basin-wide economic benefits (for all countries combined) for all five considered scenarios are considerably higher than the baseline, with the increase ranging from 36\% (under "Upstream Energy Priority") to 47\% (under "Uzbekistan Priority" and "No Priority" scenarios). In other words, the Rogun Dam has, clearly, a major potential to make the entire Amu Darya River Basin better off. 
Another key finding is that the scenario with no country priority creates only relatively little additional total benefits when compared to other scenarios. Looking more closely to the results, an interesting finding emerges: "No Priority" brings clearly less benefits to Uzbekistan than to Afghanistan, Tajikistan, and Turkmenistan (13\% against 140\%, 190\%, 322\% correspondingly). In addition, "No Priority" creates more total benefits for upstream Tajikistan than scenario maximizing Tajikistan's energy production. Yet, looking only at total benefits is not enough, but the results must also be looked at in terms of how water is being allocated during the year, as this has major impact on the energy and agricultural production (Figure 4). The implications of this are discussed below with the chapter presenting more detailed results for each riparian country. Results regarding changes in land patterns of various scenarios is presented in Appendix B.

\subsubsection{Tajikistan}

The modeling results indicate that Tajikistan is clearly better off under any scenarios than currently, i.e., under Baseline, with increased total benefits ranging from 112\% ("Downstream Agricultural Priority") to $190 \%$ ("No Priority"). Remarkable is that the total economic benefits are highest under "No Priority" (due to major increase in agricultural benefits), and not under the scenario prioritizing Tajikistan's energy use. Similarly remarkable is that Tajikistan's energy benefits are actually highest under two scenarios prioritizing the water use of Uzbekistan and Turkmenistan. Yet, in reality such schemes would not be optimal for Tajikistan due to non-optimal timing of the energy production during the year (Figure 4). As can be seen from the figure, only "Upstream Energy Priority" gives Tajikistan opportunity to produce energy throughout the year according to its likely electricity demand. However, besides significant energy surplus, "Upstream Energy Priority" results in a small 3\% decrease to baseline agricultural benefits, compared to a significant increase in the most downstream Turkmenistan $(212 \%)$ and small $11 \%$ increase in Uzbekistan.

When considering also the timing of the hydropower production, the most preferable scenario for Tajikistan would be the one prioritizing its energy use, i.e., "Upstream Energy Priority." While other scenarios also increase its total benefits (with the highest total benefits under "No Priority"), they are less optimal due to clearly less optimal timing of energy production, as well as due to reduced agricultural benefits (except for "No Priority").

\subsubsection{Uzbekistan}

Uzbekistan's total benefits increase in all modeled scenarios except "Turkmenistan Priority." This scenario means a $66 \%$ decrease of agricultural benefits in Uzbekistan, as water is redirected to Turkmenistan's agricultural sector. Among all considered scenarios the most preferable for Uzbekistan would be scenarios of prioritizing its own benefits and "Downstream Agricultural Priority", as they bring 43\% and 34\% increases, correspondingly. While Uzbekistan would experience an increase in benefits in scenarios of "Upstream Energy Priority" and "No Priority" (11\% and 13\%, correspondingly), it seems that the increase is very small to convince this country to make a switch and agree for upstream water infrastructure development.

Thus, the most preferable scenarios for Uzbekistan are "Uzbekistan Priority" and "Downstream Agricultural Priority." The difference between these scenarios relates to total economic benefits as well 
as to the possible compensations: if the country would choose "Uzbekistan Priority", it had to compensate looses for both the upstream Tajikistan and downstream Turkmenistan (and possibly Afghanistan), which could be too expensive, while in "Downstream Agricultural Priority" Uzbekistan has to make payments to upstream countries only as Turkmenistan is also better off in this scenario.

\subsubsection{Turkmenistan}

According to the model results, Turkmenistan experiences increase in agricultural benefits in all scenarios except "Uzbekistan Priority" that gives a 10\% decrease in total benefits. Agricultural benefits would increase by a remarkable 1326\% under "Turkmenistan Priority", under "Downstream Agricultural Priority" by $136 \%$, under "Upstream Energy Priority" by $212 \%$, and under "No Priority" by $322 \%$. Such remarkable increases are possible, as Turkmenistan has relatively small agricultural area (particularly when compared to Uzbekistan). As a result, the new water regime enabled by the RHP lead in the modeled scenarios to major increases in Turkmenistan's cropping area, from 0.78 million hectares to up to 1.71 million hectares under "Turkmenistan priority" (Appendix B). As result, Turkmenistan would be fine with any scenarios except "Uzbekistan Priority", although it would obviously prefer the scenario of "Turkmenistan Priority".

\subsubsection{Afghanistan}

The model results show that Afghanistan would benefit from "No Priority" $(+140 \%)$ and "Upstream Energy Priority" (76\%) and would negligibly lose in "Uzbekistan Priority" (-2\%) and in "Downstream Priority" (-4\%); "Turkmenistan Priority" doesn't change the status quo of this country. Thus, Afghanistan would be better off under the scenarios emphasizing total basin-wide benefits and Tajikistan's energy production, although it would not experience remarkable economic losses under any scenario.

\subsection{Opportunities for Benefit-Sharing Based on Total Economic Benefits}

How do the modeling results presented above link to the concept of benefit-sharing? This chapter aims to answer this question by discussing alternative ways that our modeling results indicate for benefit-sharing in the Amu Darya River Basin. The starting point for such a discussion is the conclusion that the planned Rogun Dam has a potential to increase the total economic benefits to all the riparian countries. The follow-up question is thus: what kind of scenarios and related compensation mechanisms are most realistic to provide economic benefits for all riparian countries?

To initiate such discussion, let us first look at how preferable the different operation schemes are for different countries based on the total economic benefits (Table 3). As can be seen from Tables 2 and 3, Tajikistan has, in a way, the most optimal situation, as all scenarios i.e. operation schemes are clearly more beneficial for it in terms of total economic benefits. The situation is different for Uzbekistan, Turkmenistan and Afghanistan that all have some operation schemes that are at least slightly detrimental when compared to the current situation, i.e., the baseline. Yet, a closer look at Tajikistan's situation reveals that, due to less optimal timing of energy production (Figure 4), it would not favor any other schemes except "Upstream Energy Priority" unless its energy demand is compensated in some other way. 
As a result, the key message from Table 3 is that there is no single operation scheme to simultaneously satisfy the needs of all riparian countries, indicating the need for some kind of benefit-sharing and related compensation mechanisms.

Table 3. Preferable scenarios for the riparian countries in terms of total economic benefits as derived from the model (green-desirable, yellow-acceptable, red-detrimental). *: scenario not seen desirable because of the less optimal timing of energy production.

\begin{tabular}{cccc|c}
\hline Scenario/Country & Tajikistan & Uzbekistan & Turkmenistan & Afghanistan \\
\hline Upstream Energy Priority & & & & \\
Uzbekistan Priority & & & & \\
Turkmenistan Priority & & & & \\
Downstream Agricultural Priority & & & & \\
No Priority-Optimal & $*$ & & \\
\hline
\end{tabular}

When looking at the different operation schemes and their potential for benefit-sharing (Tables 2 and 3, Figure 4), we can first exclude "Uzbekistan Priority" and "Turkmenistan Priority", as both these scenarios result in clearly detrimental impact (red color) to some other country.

Consequently, three scenarios that have the biggest potential for benefit-sharing and monetary compensation are: "Upstream Energy Priority", "Downstream Agricultural Priority", and "No Priority." These are discussed in more detail below.

\subsubsection{Upstream Energy Priority}

This scenario provides the most obvious starting point for benefit-sharing negotiations, as this scenario corresponds most closely with the probable operation of the Rogun Hydropower Plant. Interestingly, the modeled economic benefits for all four riparian countries are, under this scenario, greater than with the baseline, with Tajikistan and Afghanistan benefiting the most.

Yet, while the total economic benefits for Tajikistan and Uzbekistan are greater than currently (Baseline), the additional benefits for both countries are considerably less than with their country priority or, in the case of Uzbekistan, also with the Downstream Agricultural Priority. In addition, this scenario would result in remarkable changes in the downstream countries' land use and agricultural practices, with the timing for both cotton and wheat changed (Appendix B). As a result, the actual benefit-sharing negotiations under this scenario would most probably focus on the downstream agriculture, and the actual possibilities of Uzbekistan and Turkmenistan to initiate such a radical change in their cropping practices.

\subsubsection{Downstream Agricultural Priority}

This scenario provides another, very different way to look at the possibilities for benefit-sharing. Under this operation scheme all countries except Afghanistan (with remarkably small decline by 4\%) have considerable growth in total benefits: Tajikistan by $112 \%$, Uzbekistan by $34 \%$, and Turkmenistan by $136 \%$. While total economic benefits are considerable even for Tajikistan, this scenario is challenging for Tajikistan due to the less optimal timing of Rogun's energy production. Consequently, one solution for this is to broaden the discussion from mere water use to broader aspects of energy production, and to link the solution to regional energy trade. 
In such a setting the downstream countries of Uzbekistan and Turkmenistan need to agree to buy surplus energy produced by the Rogun Dam in summer months (as water is released for agricultural needs) and also agree to provide to Tajikistan additional energy (electricity, coal, oil, natural gas) in the winter period (when Tajikistan cannot operate Rogun, but needs to store its water for irrigation). Such a benefit-sharing scheme is actually not something new: it worked well in the former Soviet Union period (see e.g., [26]). Today, such arrangements just need political will and trust among riparian countries.

Table 4 helps to illustrate what this kind of compensation mechanism could look like in practical terms. The table presents the average energy production (GWh/month) for "Downstream Agricultural Priority" and "Upstream Energy Priority", with latter reflecting Tajikistan's ideal energy use over a year. It is clearly seen from Table 4 that if countries would pursue the "Downstream Agricultural Priority" scenario, Tajikistan would have a deficit of energy in the winter period (September-February) and a surplus of energy in the summer period (March-August). Therefore, the country will need compensation to satisfy its energy demands in the winter which, if summed up, presents $5805 \mathrm{GWh} /$ winter of electricity. Depending on an agreement, the compensation could be in the form of barter supplies (like in the former Soviet Union period - coal, natural gas or oil to burn in the country's power plants) or monetary payments so that Tajikistan could buy necessary energy from other countries. According to our estimation the monetary value could be as much as USD 230 million (at price USD0.04/kWh).

In addition, the countries would need to agree what will happen to Tajikistan's summer electricity surplus (5252 GWh per summer): Tajikistan could either sell it through regional energy markets or then Uzbekistan and Turkmenistan could agree to buy it with an agreed rate. With price USD0.04/kWh, the cost of this summer electricity surplus would be USD 210 million. Overall, the monetary transactions of the downstream countries could be close to half of billion US dollars per year, with part of it going for buying Tajikistan's summer electricity surplus and part of it compensating Tajikistan for its winter energy deficit.

Table 4. Rogun reservoir energy production in two scenarios by months, averaged over future years (GW hours/month).

\begin{tabular}{cccc}
\hline Month & Downstream Priority & Upstream Energy Priority & Difference between Scenarios \\
\hline January & 0 & 1134 & -1134 \\
February & 0 & 945 & -945 \\
March & 2670 & 1421 & 1250 \\
April & 1831 & 888 & 943 \\
May & 2536 & 962 & 1573 \\
June & 2070 & 945 & 1125 \\
July & 1120 & 976 & 144 \\
August & 1195 & 977 & 217 \\
September & 9 & 887 & -878 \\
October & 54 & 920 & -866 \\
November & 68 & 1030 & -961 \\
December & 50 & 1071 & -1021 \\
\hline
\end{tabular}




\subsubsection{No Priority (Optimising Basin-Wide Benefits)}

The scenario of "No Priority", meaning maximization of basin-wide benefits, could also be considered as a possible case for further benefits-sharing elaboration. Similarly to the "Upstream Energy Priority" scenario, also this scenario brings increase in total economic benefits for all basin countries. When compared with "Downstream Agricultural Priority" scenario, however, the total economic benefits of Uzbekistan are in this scenario almost three times less and the benefits of Turkmenistan three times more. Such a change would most likely have implications on how the downstream countries' compensation to Tajikistan is shared.

Similarly to the "Downstream Agricultural Priority" scenario, the main shortcoming of this scenario is that Tajikistan's seasonal electricity production does not follow its energy needs. As a result, also in this scenario the possible benefit sharing scheme would include compensations from downstream countries to Tajikistan to ensure its energy needs. Table 5 presents the average energy production (GWh/month) for "No Priority" and "Upstream Energy Priority", with latter reflecting Tajikistan's ideal energy use over a year. Under the "No Priority", Turkmenistan and Uzbekistan would need to compensate Tajikistan a total of $5789 \mathrm{GWh}$ of electricity per winter with an estimated price of USD 232 million (at price USD0.04/kWh). In addition, Tajikistan would also produce a total of $5229 \mathrm{GWh}$ of "surplus electricity" during the summer (electricity it does not fully need), and the downstream countries could agree to buy this energy with an estimated total cost of USD 209 million. Downstream countries would have to spend almost half of billion US dollars a year for Tajikistan (part of it buying electricity, part of it as direct compensations) in order to make sure more optimal water allocation for their irrigated agriculture.

It seems that this scenario is almost the same as the previous case, but the difference exists - in this case, benefits of Uzbekistan have been reduced by almost three times and benefits of Turkmenistan have been increased by three times, compared with the "Downstream Agricultural Priority" scenario. This could mean a change in the compensation mechanism from each country to Tajikistan and, also, between them.

Table 5. Rogun reservoir energy production in two scenarios by months, averaged over future years (GW hours/month).

\begin{tabular}{cccc}
\hline Month & No Priority & Upstream Energy Priority & Difference between Scenarios \\
\hline January & 0 & 1134 & -1134 \\
February & 0 & 945 & -945 \\
March & 2747 & 1421 & 1326 \\
April & 1900 & 888 & 1012 \\
May & 2611 & 962 & 1649 \\
June & 2043 & 945 & 1097 \\
July & 1031 & 976 & 55 \\
August & 1067 & 977 & 89 \\
September & 15 & 887 & -872 \\
October & 60 & 920 & -861 \\
November & 72 & 1030 & -958 \\
December & 51 & 1071 & -1020 \\
\hline
\end{tabular}




\section{Discussion}

\subsection{Methodological Implications: Beyond the Economic Benefits}

This study has presented an experimental case study of modeling the economic benefits related to a water infrastructure development in a transboundary river, namely the Rogun Dam in Amu Darya River Basin. For us, the largest limitation of the study is its strong focus on economic benefits alone. Yet, the benefits-sharing scheme can also include several other benefits such as environmental, social, and political, which are difficult but still possible to assign monetary value. In the specific context of the Amu Darya River Basin, the political relations between the riparian countries are currently very complex, and the geopolitical relations and power asymmetries are the greatest hindrance for any cooperative agreement.

Both Uzbekistan and Turkmenistan oppose the Rogun Hydropower Plant as it would increase Tajikistan's control over Amu Darya's flows, and in this way provide a way to impact downstream countries. Similarly, Tajikistan would most likely not be willing to agree with the "Downstream Agricultural Priority" scenario, as the compensations included in such a scenario (whether through energy bartering or monetary payments) would increase its dependency on both Uzbekistan and Turkmenistan. Despite these limitations, we believe that highlighting the common economic gains that can be achieved from the operation of Rogun also motivate the countries to try to find the political will to look at the possible benefits of transboundary cooperation.

It should also be noted that the benefits are in the model are calculated only for agricultural and energy sectors. The study does not take into consideration other economic benefits, such as those related to domestic, industrial, recreational, and navigational use. It must also be noted that benefit-sharing in its broadest sense considers all actions that change the allocation of costs and benefits associated with transboundary cooperation. Yet, the study does not, for example, take into account who would bear the cost of the Rogun Dam, which is currently financed by the government of Tajikistan and is estimated to be remarkable for this poor country (around USD 3 billion [9]).

Finally, modeling always involves inaccuracies and simplifications, arising from the limited information available. The experimental case presented here consists of a number of assumptions and simplifications that need to be taken into account when considering the results. For example, the data concerning crops, prices, water use, and return flows was sparse, while the study excluded entirely groundwater use for irrigation due to lack of reliable data. In addition, the results are based on the assumption that there exist institutions and markets that efficiently use and allocate land, water, crop, and energy as described in the scenarios. Importantly, it is also assumed that the riparian countries are able to change their agricultural cropping patterns in ways outlined in Appendix B. Although it is unfeasible to change in a short run due to regional and/or national infrastructure, soil conditions, labor and farming methods, financial support from the local governments, etc., certainly various options to do this in a long run are available.

There were several important aspects that were excluded from the model. First, the impact of climate change to the Amu Darya River Basin and its flows was not included. A comprehensive analysis would be needed to account for range of risks associated with future climate variability. Second, the optimization framework was modeled to ensure energy requirements according to the published i.e., historical monthly electricity demand in Tajikistan [27]. As a result, if electricity demand changes, also 
the actual operation scheme of the RHP could change: this would obviously impact also downstream flows. Third, the model did not consider the impacts from drought periods that are also likely to change the Rogun's operation scheme. Fourth, the model neglects the benefits that the establishment of common trade area such as common markets of agricultural commodities and energy would result in the region.

Given the experimental nature of the presented study there is a big room for improvements and further extension of the modeled framework. Even within the economic benefits, such as energy and agricultural ones considered in the current study, there are possibilities to include new dimensions and policy options, such as the establishment of a common trade, area such as common markets of agricultural commodities and energy, which are currently absent. Surely, these new policies would give a new look at ways to solve the existing problems and, hopefully, would push the basin countries to cooperate and negotiate new agreements on the ways to the sustainable management of water resources.

\subsection{Reflections on Benefit-Sharing}

The Amu Darya River Basin is considered as one of the complex food-water-energy nexus situations in transboundary river basins [28]. Today's complicated conditions are mostly related to the past situation when water, energy and agriculture of the region was managed as one integrated scheme from a central body in Moscow, which ruled "water quotas and energy barter deals to capitalize on an abundance of water resources in the upstream territories and a wealth of fossil-fuel resources in the downstream territories, respectively." [28]. As the riparian countries gained independence and the barter relations disappeared. The situation changed profoundly as several riparian countries are currently involved in a conflict over the use of scarce water, energy and food resources of the region. Desire of upstream countries to build new dams added a spark to the already conflict-prone regional affairs. In the context where each country aims for a kind of resource capture in relation to water and is not willing to negotiate cooperative water resource management, this study looks at how the idea of benefit-sharing would help the region to proceed from the current political deadlock. We believe that the concept could be useful in bringing riparian countries with opposite interests to the possible cooperation scheme.

The benefit-sharing process consists of three main phases: motivation, design, and implementation [29]. In the case of the Amu Darya River Basin, however, none of these phases from riparian countries really exists today. Given the complex political situation, our study could form a basis for a "pre-motivation" for benefit sharing. The starting point for such a phase would be the notion that the Rogun Hydropower Plant has a potential to make all riparian countries better off, and that a common benefit sharing scheme and related compensations mechanisms are actually economically feasible. The region can also search for lessons learnt from other river basins where dams have created common benefits, potential examples including the dams on the Senegal River, the Canadian dams on the Columbia River, the Lesotho Highlands Water Project on the River Orange-Senqu, the Kariba Dam on the River Zambezi, the Itaipu Dam on the Rio Parana, etc.

The possible "pre-motivation" for the benefit-sharing could be offered by the "Upstream Energy Priority", "Downstream Agricultural Priority", and "No Priority" scenarios. "Upstream Energy Priority" scenario presents the most natural starting point, as it would ensure Tajikistan's energy production and at the same time increase the agricultural benefits to downstream countries (although only through quite remarkable changes in land use and cropping practices). Yet, it would also provide a Tajikistan a means 
to control part of the Amu Darya's flow, and in this way to influence the critical agricultural sectors downstream. On the other hand, the energy benefits gained by Tajikistan could even lead the country to provide some support for the downstream countries of Uzbekistan and Turkmenistan to restructure their agriculture to better cope with the changed water flows.

Another potential options for pre-motivation are presented by the "Downstream Agricultural Priority" and the "No Priority" scenarios. Both scenarios could be viewed as a return to the benefit-sharing logic used during the Soviet period, where water is stored in upstream during the winter and released then during summer to ensure downstream irrigation. As a return, downstream states provide upstream states with energy resources (natural gas, oil, coal) during winter. While both scenarios are structurally similar, they differ in terms of the distribution of the economic benefits between downstream countries as well as in upstream Tajikistan (where the "No Priority" would lead to remarkable increase in agricultural benefits). This would also have an impact on the actual compensations mechanisms i.e., who and how much should be compensated. To help such discussion, we also compared the energy production under these scenarios with "Upstream Energy Priority" and gave also monetary estimates for their seasonal differences.

Naturally, each country wishes to maximize its own individual benefits from the river. Without any basin agreement, Tajikistan is likely to build and operate Rogun to maximize its energy benefits. Tajikistan is thus not likely to agree on any other operation scheme unless other countries offer Tajikistan some kind of compensation. However, the situation is not so simple, as in reality Tajikistan has major challenges to go ahead with Rogun without the consent of other riparian countries. Unlike upstream countries in some other river basins (for example Turkey in Tigris-Euphrates or China in Mekong River), Tajikistan is geopolitically or economically not in a strong position to pursue its own interests without agreement with its more powerful neighboring countries.

While it is at this stage difficult to foresee even the scale of future negotiations and size of monetary compensation, it seems possible that Uzbekistan could require some benefits from upstream Tajikistan and possibly also from downstream Turkmenistan, as otherwise it could use water in own agriculture without letting it flow to Turkmenistan. All basin countries would anyway need to develop some kind of agreement on the ways to utilise the changed water flows that the RHP will cause. Obviously the basis for such an agreement could stem from the Convention on the Protection and Use of Transboundary Watercourses and International Lakes of the UN System (often called the UNECE Convention or the Helsinki Convention), as the downstream countries Uzbekistan and Turkmenistan already have ratified the convention at the time of writing of this paper [30].

\section{Conclusions}

With increasing resource scarcities, the water, food and energy nexus is growing in importance. Addressing conflict among these closely interrelated domains is considered increasingly important for equity and sustainability in transboundary river basins. The issue complex but it requires careful consideration by reviewing existing best practices, identifying new approaches, and implementing state-of-the-art principles and processes. This article argues that despite the basin-scale and sectoral challenges in the Amu Darya River Basin, the concept of benefit sharing could be utilized to find a way that enhances the economic benefits and, ultimately, water, energy and food security for all riparian countries. Due to its history as “one basin' under the Soviet regime, the basin provides an interesting 
case on how the water use has developed. After the collapse of the Soviet Union, newly independent Central Asian nations prioritized the own food, water and energy security as well as agricultural trade to the detriment of basin-wide integrated management.

Amu Darya River Basin is shared by four riparian countries with different interests in utilizing the River's water for agricultural and energy production. Water, food and energy security issue in the region has been extensively under consideration in recent years. The conflicting situation between upstream countries willing to enhance energy security and downstream countries willing to continue with status quo because of fearing for their food security could worsen current geopolitical situation. Well-known and increasingly popular concepts of basin-wide benefits optimization may not work in such conflict prone conditions without a process of negotiation with sound motivation and commitment. Even at the national level, management of water, energy and agriculture remains almost exclusively sector based. The water, energy and agriculture nexus can thus be used as a mechanism for both conflict resolution and development. However, current situation presents clear conflict between upstream energy development and downstream agricultural development, energy versus food security in relevant countries. Current political situation leaves almost no room for possible maneuver.

This study provides an experimental case study on how the concept of benefit-sharing could be used to motivate the riparian countries to enhance their cooperation in the development of their shared water resources. The used hydro-economic model used provides specific estimates on the total economic benefits that different operation schemes (scenarios) of the planned Rogun Hydropower Plant could bring for each riparian country. While the model can suggest an optimal scenario for the entire basin (with no country priorities), it may not be optimal for a particular basin country. Yet, we recognised three different scenarios - "Upstream Energy Priority", "Downstream Energy Priority", and "No Priority" - that could all be used as a starting point for further negotiations about benefit-sharing and related compensation mechanisms. The scenarios help each riparian country to see the potential for benefits - and their limits - associated with cooperating in a regional, basin-wide agreement across water-energy-agriculture nexus.

\section{Acknowledgments}

The study was done under the Academy of Finland funded NexusAsia project (269901). The authors wish like to thank the colleagues at Aalto University's Water \& Development Research Group for their support. Special thanks go to Ms Miina Porkka for providing map of Central Asia (Figure 1).

\section{Author Contributions}

Shokhrukh-Mirzo Jalilov developed the hydro-economic model used in the analysis, producing and interpreting its results, and writing majority of the article. Marko Keskinen and Olli Varis contributed in defining the scope of the article and wrote parts of the Introduction, Discussion and Conclusions sections.

\section{Conflicts of Interest}

The authors declare no conflict of interest. 


\section{Appendix A}

The model and its documentation were originally developed for application to the Amu Darya Basin in the Central Asia. However, it is adaptable to the hydrology, water infrastructure development, land use patterns, economics, and institutions of any basin. The essential principle of the hydrology component of model is mass balance-for surface flow, water diversions and water depletions for use in irrigated agriculture. Important variables tracked include water storage capacity, crop mix, land in production, and farm income. The model structure is defined below using the GAMS notation, described by the vendor at gams.com.

\section{A.1. Sets}

Sets are the dimensions over which the storage scaling model is defined. A similar structure could be used for reservoir capacity analysis anywhere new water storage is planned. The following sets and set elements are used:

$\begin{array}{lll}i & \text { Flows } & \text { /inflow, river, divert, use, return, release/ } \\ u & \text { Stocks } & \text { /reservoir/ } \\ t & \text { Months } & \text { /January-December/ } \\ y & \text { Years } & \text { /1-10/ } \\ j & \text { crop } & \text { /cotton, wheat, vegetables/ } \\ k & \text { crop season } & \text { /first, second/ } \\ n & \text { water supply scenario } & \text { /base, dry/ } \\ p & \text { Policy } & \text { /Baseline, Energy, UZ, TK, Downstream, OPTIM/ } \\ s & \text { Region countries } & \text { /Afghanistan, Tajikistan, Turkmenistan, Uzbekistan/ }\end{array}$

\section{A.2. Data}

Some of the following parameters (data) terms end in $p$ to distinguish parameters (unknown terms) from unknown variables. Parameters are:

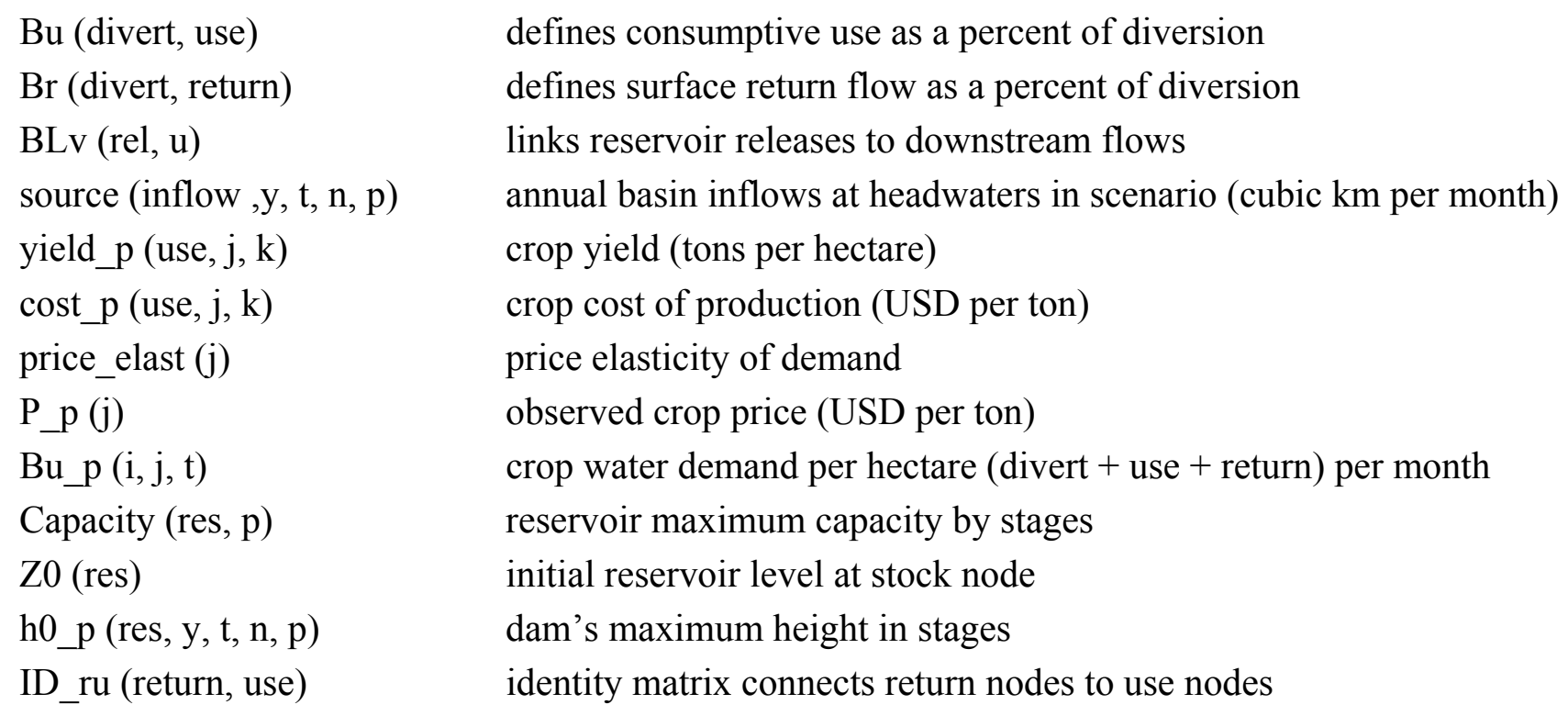


ID_du (divert, use) identify matrix connects divert nodes to use nodes

Landrhs_p (use) Irrigated land area by countries (million hectares)

hydro_price (res, t) price of hydropower (constant USD per kWh)

\section{A.3. Variables (Unknowns)}

Some of unknown variable ends in $\mathrm{v}$, to distinguish variables from known data. The model solves for the optimal value of each of these variables, for which the goal is to maximize total basin net economic benefits.

\section{A.3.1. Positive Variables}

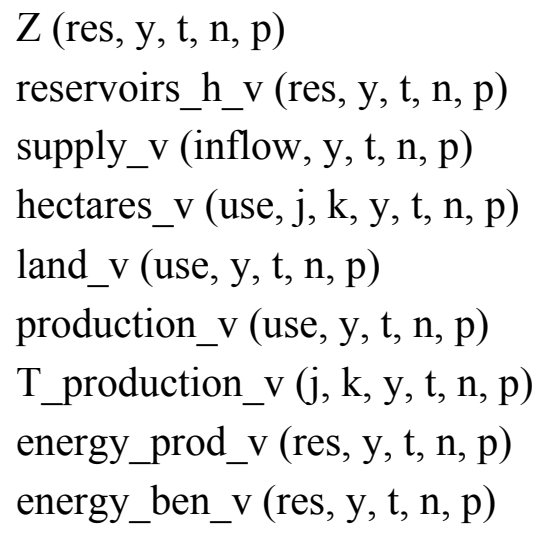

\section{A.3.2. Free variables}

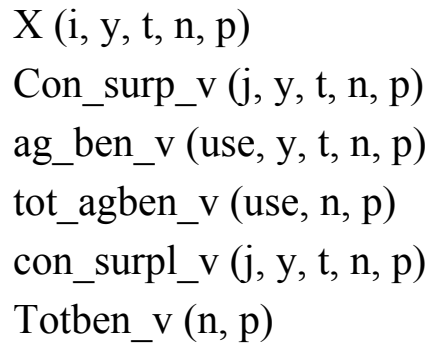

\section{A.4. Equations}

\section{A.4.1. Hydrology}

The essential principle of the hydrology is mass balance, both for surface flow interactions, reservoir levels. The hydrology uses mass balance principles to account for headwater flows, river flows, reservoir levels, water from surface applied to various uses, and the impact of surface flows on current and future reservoir storage levels.

\section{A.4.1.1. Headwater Runoff}

$$
X(\text { inflow, } y, t, n, p)=\text { source (inflow, } y, t, n, p)
$$




\section{A.4.1.2. River Flow}

$$
\begin{aligned}
X(\text { river, } y, t, n, p)= & \text { sum }(\text { inflow, Bv }(\text { inflow, river }) \times X(\text { inflow, } y, t, n, p))+ \\
& \text { sum }(\text { riverp, Bv }(\text { riverp, river }) \times X(\text { riverp, } y, t, n, p))+ \\
& \text { sum }(\text { divert, Bv }(\text { divert, river }) \times X(\text { divert, } y, t, n, p))+ \\
& \text { sum }(\text { return, Bv }(\text { return, river }) \times X(\text { return, } y, t, n, p))+ \\
& \text { sum }(\text { rel, Bv }(\text { rel, river }) \times X(\text { rel, } y, t, n, p))
\end{aligned}
$$

\section{A.4.1.3. Water Diverted}

$$
\begin{array}{r}
X(\text { divert, } y, \mathrm{t}, \mathrm{n}, \mathrm{p})=\operatorname{sum}\left((\mathrm{j}, \mathrm{k}), \mathrm{Bu} \_\mathrm{p}(\text { divert, } \mathrm{j}, \mathrm{t})\right. \\
\times \\
\times \operatorname{sum}\left(\mathrm{use}, \mathrm{ID} \_ \text {du (divert, use }\right) \\
\end{array}
$$

A.4.1.4. Gross Surface Returns to River

$$
\begin{array}{r}
X(\text { return, } y, t, n, p)=\operatorname{sum}\left((j, k), B u \_p(\text { return, j, t })\right. \\
\times \text { sum (use, ID_ru (return, use) } \\
\times \text { hectares_v (use, j, k, y, t, n, p) }
\end{array}
$$

\section{A.4.1.5. Water Consumed}

Any water use node's consumptive use, it is an empirically-determined proportion of total water applied. For irrigation, consumptive is the quantity of water lost through plant evapotranspiration (ET) to any future use in the system. For agricultural nodes, water use is measured as:

$$
X(\text { use, } y, t, n, p)=\operatorname{sum}\left((j, k), B u \_p(u s e, j, t) \times\right. \text { hectares_v (use, j, k, y, t, n, p) }
$$

For hydropower generation use, consumptive use is the quantity of water flowing through turbines. However, that water quantity could be reused for irrigation if it fits right time. That water use generates energy, which cannot be negative. It is measured as:

$$
\mathrm{Z}(\text { res, } \mathrm{y}, \mathrm{t}, \mathrm{n}, \mathrm{p})=\mathrm{Z} 0(\text { res })-\operatorname{sum}(\text { rel, BLV }(\text { rel, res }) \times \mathrm{X}(\text { rel, } y, \mathrm{t}, \mathrm{n}, \mathrm{p}))
$$

Energy production is total water flow to generate energy in month of year, in scenario and policy. Remaining coefficients are: g-gravitational constant $(g=9.8 \mathrm{~N} / \mathrm{kg}) ; \mathrm{E}$, Efficiency, which can vary from 0 to 1 , and transformation coefficients.

$$
\text { Energy_prod_e }(\text { res, } y, t, n, p)=X(y, t, n, p) \times 9.8 \times 0.75 \times 24 \times(365 / 12)
$$

\section{A.4.1.6. Reservoir Storage}

Reservoir contents are:

$$
\begin{gathered}
\mathrm{Z}(\mathrm{res}, \mathrm{y}, \mathrm{t}, \mathrm{n}, \mathrm{p})=\operatorname{sum}((\mathrm{y} 2, \mathrm{t} 2), \mathrm{Z}(\mathrm{res}, \mathrm{y} 2, \mathrm{t} 2, \mathrm{n}, \mathrm{p})-\operatorname{sum}(\operatorname{rel}, \mathrm{BLv}(\mathrm{rel}, \mathrm{res}) \times X(\text { rel, } \\
y, \mathrm{t}, \mathrm{n}, \mathrm{p})
\end{gathered}
$$

Electric power comes from building a Reservoir on a river that has a large drop in elevation. There are few hydroelectric plants in flat places. The dam stores water behind it in the reservoir, and a higher storage volume of water in the reservoir means that the water falls a greater distance and reaches a greater velocity when passing through the turbines. The turbine converts the energy of flowing water into 
mechanical energy. The hydroelectric generator converts this mechanical energy into electricity. The hydraulic head for the reservoir's dam in the month of year, scenario and policy was empirically estimated to fit conditions for the Rogun reservoir:

$$
\text { Reservoir_h (res, y, t, n, p) }=3698.10229-3451.26986 \times(1 /(z(\text { res, y, t, n, p) + 0.001) × 0.01) })
$$

The idea of these coefficients is: on the basis of known limited data on Rogun reservoir's water volume which depends on height of dam to find nonlinear relation between storage volume and head of the dam, so we could exactly predict what would be head having certain water volume. Contents of the reservoir in the initial period $(0), \mathrm{Z} 0$ :

$$
\mathrm{Z} 0=0
$$

The upper bound on the reservoir's contents is defined as:

$$
\mathrm{Zmax}=\mathrm{C}
$$

This equation guarantees that the reservoir's level never exceeds its capacity. Policies that would change a reservoir's capacity, such as dredging or adding to a dam's height, are simulated by altering the value of $\mathrm{C}$.

\section{A.5. Land Use}

Land use patterns affect the demand for water. For irrigated agriculture, total land in production is expressed as:

$$
\text { Sum }((j, k) \text {, hectares_v (use, j, k, y, t, n, p) = land_v (use, y, t, n, p) }
$$

This states that irrigated land in production by node, crop, season, and time, summed over crops and seasons cannot exceed available land (RHS) by node, time period for any given scenario and policy. In most dry rural regions of the world, like the Amu Darya Basin, water is often more limiting than land. While we used the maximum current capacity in irrigated land for countries of the Basin as the upper limit on available land, more area will likely become available if greater long term water supplies can be secured and if institutions adjust to permit the extra water to be used by agriculture.

The baseline policy analysis is constrained to replicate historical irrigated land by country and crop. For the two alternative policies, those constraints are removed by allowing water tradeoffs to occur, either within a single or among irrigated areas. Either policy permits existing water to be reallocated to higher economic valued water uses where the economics would support such a reallocation.

\section{A.6. Economics}

Economic benefits are produced by water depletions at use nodes for irrigated agriculture and by the water flowing through turbines to generate energy at reservoir nodes. For agricultural uses, the willingness to pay is measured by the contribution of water to net farm income which equals crop price multiplied by yield minus cost of production plus any unpriced consumer surplus. Consumer surplus is an unpriced value, equal to the amount by which power buyers' economic welfare exceeds the actual price charged. It is measured as the area beneath the demand function and above actual price charged: 


$$
\begin{aligned}
& \text { Con_surp_v }(j, y, t, n, p)=0.5 \times\left(b 0 \_p(j)-C \operatorname{Crop} \_p r i c e \_v(j, y, t, n, p)\right] \times \operatorname{sum}(k, \\
&\text { T_production_v }(j, k, y, t, n, p))
\end{aligned}
$$

For energy benefits, total revenue is measured as the price of electricity multiplied by the quantity produced. In the current implementation of the model, that electricity price is set at recent observed levels in the basin. Reduced prices from additional hydropower will raise consumer surplus, while increased prices will reduce consumer surplus. For regions of the basin that currently have little access to power, increases in consumer surplus are economically and politically very important to achieve:

$$
\text { Energy_ben_v }(\text { res, } y, t, n, p)=\text { energy_prod_v }(\text { res, } y, t, n, p) \times \text { hydro_price }(\text { res, } t)
$$

Agricultural benefits are measured as:

$$
\text { Ag_ben_v (use, } y, t, n, p)=\operatorname{sum}\left((j, k),\left(P \_p(j) \times \text { yield } \_p(u s e, j, t)-\operatorname{cost} \_p(u s e, j, t)\right)\right.
$$

Price of particular crop is a negatively sloping demand function, which means that one price is set for each crop for all riparian countries, so any crop could be grown in the most favorable conditions. What this means is that:

$$
\begin{gathered}
\text { Crop_price_v }(j, y, t, n, p)=b 0 \_p(j)+b 1 \_p(j) \times \\
\operatorname{sum}\left(k, T \_p r o d u c t i o n \_v(j, k, y, t, n, p)\right)
\end{gathered}
$$

The empirically estimated coefficients $b 0 \_p$ and $b 1 \_p$ are linearized demand function based on estimated price elasticities.

To measure total crop production following equation is used:

$$
\text { T_production_v }=\text { sum (use, production_v (use, j, k, y, t, n, p)) }
$$

\section{A.7. Discounted Net Present Value}

Finally, the basin scale integrated model maximizes discounted net present value across all water uses, water environments, and time periods subject to hydrologic and institutional constraints:

$$
\begin{aligned}
& \text { DNPV }=\operatorname{sum}((u, t, y) \times \text { Ag_ben_v (use, } y, t, n, p) /\left(1+r_{u}\right)^{t}+ \\
& \text { Energy_ben_v (res, } y, t, n, p) /\left(1+r_{u}\right)^{t}
\end{aligned}
$$

This says that the net present value of total water - based benefits for all nodes in Amu Darya Basin sums income over countries and time-periods, which discounts future incomes more heavily when there is a higher discount rate. The current model implementation uses a 5\% discount rate. The model allocates water among the basin's water uses, locations, and time periods to maximize $D N P V$, subject to stated constraints.

\section{Appendix B}

Table A1 shows results of land area under crop production by country, scenario, crop, and cropping season. As can be seen most scenarios give chance to the basin countries to increase their irrigated land compared to the baseline scenario. Upstream Tajikistan and Afghanistan don't have any areas under cotton, because the model optimizes its production to downstream countries where cost of production is smaller and yield is higher; also, upstream mountainous and cool climate areas could be not very suitable for cotton production. Among all countries only Afghanistan shows no reduction of land under 
production in any scenarios. As this country doesn't have large irrigated land in the basin and doesn't withdraw much water directly from Amu Darya on compare to other riparians, thus below analysis will be about other three basin countries.

Table A1. Land under production by country, crop, season, and scenario, averaged over future years (millions of hectares/season).

\begin{tabular}{|c|c|c|c|c|c|c|c|c|}
\hline \multirow[b]{2}{*}{ Country } & \multirow[b]{2}{*}{ Scenario } & \multicolumn{2}{|c|}{ Cotton } & \multicolumn{2}{|c|}{ Wheat } & \multicolumn{2}{|c|}{ Vegetables } & \multirow{2}{*}{$\begin{array}{l}\text { Total } \\
\text { Land }\end{array}$} \\
\hline & & $\begin{array}{c}\text { Planted } \\
\text { in March }\end{array}$ & $\begin{array}{l}\text { Planted } \\
\text { in May }\end{array}$ & $\begin{array}{c}\text { Planted } \\
\text { in March }\end{array}$ & $\begin{array}{c}\text { Planted in } \\
\text { May }\end{array}$ & $\begin{array}{c}\text { Planted } \\
\text { in March }\end{array}$ & $\begin{array}{l}\text { Planted } \\
\text { in May }\end{array}$ & \\
\hline \multirow{6}{*}{ Tajikistan } & Baseline-No dam & 0.00 & 0.00 & 0.22 & 0.00 & 0.03 & 0.06 & 0.30 \\
\hline & $\begin{array}{c}\text { Upstream Energy } \\
\text { Priority }\end{array}$ & 0.00 & 0.00 & 0.18 & 0.00 & 0.07 & 0.02 & 0.27 \\
\hline & Uzbekistan Priority & 0.00 & 0.00 & 0.22 & 0.00 & 0.03 & 0.03 & 0.28 \\
\hline & $\begin{array}{c}\text { Turkmenistan } \\
\text { Priority }\end{array}$ & 0.00 & 0.00 & 0.22 & 0.00 & 0.03 & 0.03 & 0.28 \\
\hline & $\begin{array}{c}\text { Downstream } \\
\text { Priority }\end{array}$ & 0.00 & 0.00 & 0.22 & 0.00 & 0.03 & 0.02 & 0.26 \\
\hline & No Priority-Optimal & 0.00 & 0.00 & 0.53 & 0.00 & 0.09 & 0.01 & 0.64 \\
\hline \multirow{6}{*}{ Afghanistan } & Baseline-No dam & 0.00 & 0.00 & 0.08 & 0.00 & 0.00 & 0.00 & 0.08 \\
\hline & $\begin{array}{c}\text { Upstream Energy } \\
\text { Priority }\end{array}$ & 0.00 & 0.00 & 0.12 & 0.00 & 0.01 & 0.00 & 0.13 \\
\hline & Uzbekistan Priority & 0.00 & 0.00 & 0.08 & 0.00 & 0.00 & 0.00 & 0.08 \\
\hline & $\begin{array}{c}\text { Turkmenistan } \\
\text { Priority }\end{array}$ & 0.00 & 0.00 & 0.08 & 0.00 & 0.00 & 0.00 & 0.08 \\
\hline & $\begin{array}{c}\text { Downstream } \\
\text { Priority }\end{array}$ & 0.00 & 0.00 & 0.08 & 0.00 & 0.00 & 0.00 & 0.08 \\
\hline & No Priority-Optimal & 0.00 & 0.00 & 0.22 & 0.01 & 0.01 & 0.00 & 0.23 \\
\hline \multirow{6}{*}{ Uzbekistan } & Baseline-No dam & 0.04 & 0.74 & 1.08 & 0.02 & 0.00 & 0.00 & 1.88 \\
\hline & $\begin{array}{c}\text { Upstream Energy } \\
\text { Priority }\end{array}$ & 0.50 & 0.33 & 0.62 & 0.45 & 0.00 & 0.00 & 1.90 \\
\hline & Uzbekistan Priority & 0.99 & 0.11 & 0.08 & 1.33 & 0.05 & 0.00 & 2.57 \\
\hline & $\begin{array}{c}\text { Turkmenistan } \\
\text { Priority }\end{array}$ & 0.04 & 0.19 & 1.08 & 0.02 & 0.00 & 0.00 & 1.33 \\
\hline & $\begin{array}{c}\text { Downstream } \\
\text { Priority }\end{array}$ & 0.95 & 0.11 & 0.17 & 1.40 & 0.00 & 0.01 & 2.62 \\
\hline & No Priority-Optimal & 0.80 & 0.08 & 0.31 & 1.29 & 0.00 & 0.00 & 2.49 \\
\hline \multirow{6}{*}{ Turkmenistan } & Baseline-No dam & 0.32 & 0.00 & 0.31 & 0.15 & 0.00 & 0.00 & 0.78 \\
\hline & $\begin{array}{c}\text { Upstream Energy } \\
\text { Priority }\end{array}$ & 0.45 & 0.01 & 0.17 & 0.31 & 0.00 & 0.00 & 0.94 \\
\hline & Uzbekistan Priority & 0.01 & 0.00 & 0.31 & 0.45 & 0.00 & 0.00 & 0.77 \\
\hline & $\begin{array}{c}\text { Turkmenistan } \\
\text { Priority }\end{array}$ & 0.90 & 0.00 & 0.01 & 0.76 & 0.04 & 0.00 & 1.71 \\
\hline & $\begin{array}{c}\text { Downstream } \\
\text { Priority }\end{array}$ & 0.04 & 0.00 & 0.39 & 0.35 & 0.06 & 0.00 & 0.84 \\
\hline & No Priority-Optimal & 0.45 & 0.02 & 0.08 & 0.40 & 0.00 & 0.00 & 0.95 \\
\hline
\end{tabular}


Tajikistan could experience a reduction of irrigated land under production in all scenarios except "No Priority" scenario. This happens due to fact that water is redirected to produce energy ("Upstream Energy Priority") or to irrigate more profitable downstream cotton and wheat areas in "Uzbekistan Priority", "Turkmenistan Priority", and "Downstream Priority" scenarios. Noticeably, "No Priority" scenario allows Tajikistan more than double irrigated land and increase land under wheat production which means increase food security for the country.

Uzbekistan could have reduction of cropping area in the scenario of Turkmenistan agriculture prioritization but would have considerable land increase in all scenarios except "Upstream Energy Priority." This means if the reservoir under construction would be managed in a way to pursue agricultural interests of Uzbekistan or both Uzbekistan and Turkmenistan or basin-wide benefits it would potentially be source for economic development in this country, particularly in its Amu Darya region.

Finally, Turkmenistan could have minor reduction of irrigated area in scenario "Uzbekistan Priority" but could have increase in all other scenarios. Thus, the Rogun reservoir would bring agricultural development to this country as well.

As far as crop differentiation by countries, Uzbekistan is the major cotton producer in the region with almost a million hectares of land occupied by this strategic cash crop. Uzbekistan is followed by Turkmenistan in cotton production in the region. Wheat is the major food crop for all countries in the Amu Darya basin and performs an important role in regional food security. Similarly to cotton, Uzbekistan has the most land under wheat cultivation, followed by Turkmenistan. However, since wheat is essential for food security, it also makes up an important part of the crop mix in both Tajikistan and Afghanistan.

\section{References}

1. Sadoff, W.C.; Grey, D. Cooperation on International Rivers: A Continuum for Securing and Sharing Benefits. Water Int. 2005, 30, 420-427.

2. Sadoff, C.W.; Grey, D. Beyond the river: The benefits of cooperation on international rivers. Water Policy 2002, 4, 389-403.

3. Klaphake, A. Kooperation an Internationalen Flüssen aus Ökonomischer Perspektive: Das Konzept des Benefit Sharing; Deutsches Institut für Entwicklungspolitik: Bonn, Germany, 2005. Available online: http://www.die-gdi.de/uploads/media/6-2005.pdf (accessed on 28 August 2015).

4. Phillips, D.J.H.; Daoudy, M.; Öjendal, J.; Turton, A.R.; McCaffrey, S. Trans-boundary Water Cooperation as a Tool for Conflict Prevention and for Broader Benefit-Sharing; Expert Group on Development Issues, Department for International Development Cooperation; Ministry of Foreign Affairs: Stockholm, Sweden, 2006. Available online: http://www.eldis.org/go/home\&id=22735\& type=Document\#.Vd_-DdK1_mM (accessed on 28 August 2015).

5. Qaddumi, H. Practical Approaches to Transboundary Water Benefit Sharing; Overseas Development Institute: London, UK, 2008.

6. Lee, S. Benefit sharing in the Mekong River basin. Water Int. 2014, 40, 139-152. 
7. Bekchanov, M.; Bhaduri, A.; Ringler, C. Is Rogun a Silver Bullet for Water Scarcity in Central Asia? Center for International Development and Environmental Research: Giessen, Germany, 2013. Available online: http://ageconsearch.umn.edu/bitstream/159075/2/ Bekchanovetal2013aRogunimpactfinal.pdf (accessed on 31 May 2014).

8. Jalilov, S.; Amer, S.; Ward, F. Reducing conflict in development and allocation of transboundary Rivers. Eurasian Geogr. Econ. 2013, 54, 78-109.

9. Jalilov, S.; Amer, S.; Ward, F. Water, food, and energy security: An elusive search for balance in central Asia. Water Resour. Manag. 2013, 27, 3959-3979.

10. Kim, Y.; Indeo, F. The new great game in central Asia post 2014: The US "New Silk Road" strategy and Sino-Russian rivalry. Commun. Post Commun. Stud. 2013, 46, 275-286.

11. Arbour, L. Next year's wars. Foreign Policy, 22 February 2011. Available online: foreignpolicy.com/2011/12/27/next-years-wars-2/ (accessed on 28 August 2015).

12. Wegerich, K. Coping with disintegration of a River-Basin management system: Multidimensional issues in central Asia. Water Policy 2004, 6, 335-344.

13. Spoor, M.; Krutov, A. The power of water in a divided central Asia. Perspect. Glob. Dev. Technol. 2003, 2, 593-614.

14. Wegerich, K. Hydro-hegemony in the Amu Darya Basin. Water Policy 2008, 10, 71-88.

15. Central Intelligence Agency (CIA). The World Factbook. Uzbekistan. Available online: https://www.cia.gov/library/publications/resources/the-world-factbook/geos/uz.html (accessed on 28 August 2015).

16. Glantz, M. Water, climate, and development issues in the Amu Darya Basin. Migr. Adapt. Strateg. Glob. Chang. 2005, 1, 23-50.

17. Schlüter, M.; Herrfahrdt-Pähle, E. Exploring resilience and transformability of a river basin in the face of socioeconomic and ecological crisis: An example from the Amu Darya River Basin, central Asia. Ecol. Soc. 2011, 16, 32-45.

18. Schlüter, M.; Savitsky, A.; McKinney, D.; Lieth, H. Optimizing long-term water allocation in the Amu Darya River delta: A water management model for ecological impact assessment. Environ. Model. Softw. 2005, 20, 529-545.

19. CA Water Info. Scientific-Information Center of the Interstate Commission for Water Coordination in Central Asia. 2015. Available online: http://www.cawater-info.net/index_e.htm (accessed on 28 August 2010).

20. Schmidt, R. Onwards and Upwards. Water Power Magazine. 2008. Available online: http:/www.waterpowermagazine.com/features/featureonwards-and-upwards/ (accessed on 28 August 2015).

21. Brooke, A.; Kendrick, D.; Meeraus, A.; Raman, R. GAMS Language Guide; GAMS Development Corporation: Washington, DC, USA, 2006.

22. UNECE. Our Waters: Joining Hands across Borders. First Assessment of Transboundary Rivers, Lakes and Groundwaters. 2007. Available online: www.unece.org/env/water/blanks/assessment/ assessmentweb_full.pdf (accessed on 28 August 2015). 
23. World Bank. Irrigation in Central Asia. Social, Economic and Environmental Considerations. 2003. Available online: http://siteresources.worldbank.org/ECAEXT/Resources/publications/ Irrigation-in-Central-Asia/Irrigation_in_Central_Asia-Full_Document-English.pdf (accessed on 28 August 2015).

24. The Rogunskaya Hydro Power Station, Performance Characteristics. Dushanbe. Tajikistan Open Joint Stock Holding Company "Barki Tojik". 2009. Available online: http://www.tjus.org/Copy\% 20of\%20Rogynskaya\%20GES\%20_English\%20version1.pdf (accessed on 25 September 2012).

25. FACT SHEET. TALCO Energy Audit: Improved Efficiency Could Help Solve Winter Electricity Shortages. December 2012; in Financial Assessment of Barki Tojik, World Bank, October 2013. Available online: http://www.worldbank.org/content/dam/Worldbank/document/tj-talco-energyaudit-fact-sheet.pdf (accessed on 28 August 2015).

26. Soliev, I.; Wegerich, K.; Kazbekov, J. The Cost of Benefit Sharing, the Case of the Ferghana Valley in the Syr Darya Basin. Water 2015, 7, 2728-2752.

27. The International Bank for Reconstruction and Development. The World Bank. Tajikistan's Winter Energy Crisis: Electricity Supply and Demand Alternatives. November 2012. Available online: http://siteresources.worldbank.org/ECAEXT/Resources/TAJ_winter_energy_27112012_Eng.pdf (accessed on 30 May 2014).

28. Ozment, S.; DiFrancesco, K.; Gartner, T. The Role of Natural Infrastructure in the Water, Energy and Food Nexus, Nexus Dialogue Synthesis Papers; IUCN: Gland, Switzerland, 2015. Available online: http://www.iwa-network.org/downloads/1438744856-Natural\%20Infrastrucure $\% 20$ in $\% 20$ the \%20Nexus_Final\%20Dialogue\%20Synthesis\%20Paper\%202015.pdf (accessed on 28 August 2015).

29. Sadoff, C.; Greiber, T.; Smith, M.; Bergkamp, G. Share-Managing Water across Boundaries; IUCN: Gland, Switzerland, 2008.

30. United Nations Treaty Collection. Chapter XXVII Environment, 5. Convention on the Protection and Use of Transboundary Watercourses and International Lakes; United Nations Office of Legal Affairs: New York, NY, USA, 2015. Available online: https://treaties.un.org/Pages/ViewDetails. aspx src $=$ TREATY\&mtdsg_no=XXVII-5\&chapter=27\&lang=en (accessed on 27 August 2015).

(C) 2015 by the authors; licensee MDPI, Basel, Switzerland. This article is an open access article distributed under the terms and conditions of the Creative Commons Attribution license (http://creativecommons.org/licenses/by/4.0/). 